\title{
Species composition and distribution of rust fungi in Zailisky Alatau (Kazakhstan)
}

\author{
Yelena Rakhimova ${ }^{1 *}$, Gulnaz Sypabekkyzy ${ }^{1,2}$, Lyazzat Kyzmetova $^{1}$, and Assem Assylbek ${ }^{1}$ \\ ${ }^{1}$ Institute of Botany and Phytointroduction, 050040 Almaty, Kazakhstan \\ ${ }^{2}$ al-Farabi Kazakh National University, 050040 Almaty, Kazakhstan
}

\begin{abstract}
Mycobiota of the Zailisky Alatau includes 176 species of rust fungi, the Microbotryomycetes class has 5 species, the Pucciniomycetes class is represented with 171 species. The largest number of species is characteristic of the genera Puccinia (98 species) and Uromyces (24 species). Others genera are represented with 1-13 species. The greatest number of species of rust fungi is noted for altitudes of 1700-1900 and 1900-2100 m above sea level, what correlates with the vegetation zone of dark coniferous forests and meadows. Great aridity does not allow fungi to develop intensively in the lower foothills and steppe zone, and low temperatures and intense solar insolation inhibit the development of rust fungi in the alpine and subalpine zones. 337 plant species from 165 genera are registered as host plants. The largest number of rust fungi species is noted in the Small and Big Almaty gorges (73 and 57 species, respectively), in the Talgar and Turgen gorges (57 and 63 species, respectively). The gorges of Karakastek, Ush-Konyr, Uzyn-Kargaly, Chemolgan, Small Kemin and Oi-Karagai are characterized by an insignificant diversity of rust fungi (from 3 to 8 species), which is associated with lower humidity of these gorges.
\end{abstract}

\section{Introduction}

Rust fungi are the largest group of obligate plant pathogens and are characterized with a complex life cycle that takes place on one or more hosts. Rust fungi in the Zailisky Alatau began to be intensively studied since the 1950s. In 1956, G.S. Nevodovsky published detailed descriptions of rust fungi in Kazakhstan, some of which were found in Zailisky Alatau [1]. The work of B.K. Kalymbetov [2], devoted to the mycobiota of Zailisky Alatau, contains information on 249 species of rust fungi, however, the author included species living in neighboring territories, thereby significantly overestimated the number of species. Monograph of S.A. Abiev [3] presents a list and descriptions of rust fungi parasitizing on cereals in Kazakhstan. However, at present this information is quite outdated (especially, taxonomy of species).

The purpose of this article was to study the diversity of rust fungi in Zailisky Alatau and their distribution depending on the habitat of the host plants, altitudinal zonality and geographical location.

* Corresponding author: evrakhim@mail.ru 


\section{Materials and methods}

The study was performed with route methods on the territory of Zailisky Alatau (southeastern region of Kazakhstan) for several years (2010, 2012-2019). Various plant organs with typical symptoms of rust disease were collected. The coordinates of each collection site were determined using GPS (Germin). The Canon 600E digital camera was used for photographing of rust symptoms. To determine the fungi, temporary preparations were prepared which were studied and photographed using a photomicroscope Polyvar with Nomarsky interference optics (Reichert, Austria). Samples were identified based on morphological features using of determination literature focused on rust fungi [1, 4-6].

The systematics of the taxa is given in accordance with Kirk et al. [7]. Samples of rust fungi of Zailisky Alatau, located in the herbarium of the Institute of Botany and Phytointroduction (AA), were also included in the list. The similarity level of the species composition of rust fungi in Zailisky Alatau and nearby territories was determined with the Jaccard $(\mathrm{Kj})$ and the Sørensen similarity coefficients $(\mathrm{Ks})$.

\section{Results}

According to the data obtained, the mycobiota of Zailiysky Alatau includes 176 species of rust fungi (Table 1) from two classes. The Microbotryomycetes class has only 5 species belonging to the Microbotryaceae family of the order Microbotryales. The Pucciniomycetes class is represented with 171 species from 14 genera, 6 families, and 1 order. The largest number of species is characteristic of the genera Puccinia (98 species) and Uromyces (24 species). Others genera are represented with 1-13 species. Six genera contain 1 species each.

Table 1. Taxonomic structure of biota of rust fungi in Zailisky Alatau

\begin{tabular}{|c|c|c|c|c|}
\hline Class & Order & Family & Genus & $\begin{array}{c}\text { Number } \\
\text { of species }\end{array}$ \\
\hline \multirow{2}{*}{$\begin{array}{l}\text { Microbotryom } \\
\text { ycetes }\end{array}$} & \multirow{2}{*}{ Microbotryales } & \multirow{2}{*}{ Microbotryaceae } & Microbotryum & 4 \\
\hline & & & Sphacelotheca & 1 \\
\hline \multirow{14}{*}{$\begin{array}{l}\text { Pucciniomy } \\
\text { cetes }\end{array}$} & \multirow{14}{*}{ Pucciniales } & Insertae sedis & Aecidium & 10 \\
\hline & & \multirow[b]{2}{*}{ Coleosporiaceae } & Chrysomyxa & 2 \\
\hline & & & Coleosporium & 1 \\
\hline & & Melampsoraceae & Melampsora & 7 \\
\hline & & \multirow{2}{*}{ Phragmidiaceae } & Phragmidium & 13 \\
\hline & & & Trachyspora & 1 \\
\hline & & \multirow{4}{*}{ Pucciniaceae } & Gymnosporangium & 5 \\
\hline & & & Peristemma & 1 \\
\hline & & & Puccinia & 98 \\
\hline & & & Uromyces & 24 \\
\hline & & \multirow{3}{*}{ Pucciniastraceae } & Hyalopsora & 1 \\
\hline & & & Melampsoridium & 1 \\
\hline & & & Pucciniastrum & 4 \\
\hline & & Uropyxidaceae & Tranzschelia & 3 \\
\hline Total & 2 & 7 & 16 & 176 \\
\hline
\end{tabular}

The greatest number of species of rust fungi is noted for altitudes of 1700-1900 and 1900-2100 m above sea level (Figure 1), what correlates with the vegetation zone of dark coniferous forests and meadows [8]. There are somewhat less rust fungi in the zone of small-leaved forests at an altitude of 1400-1700 m above sea level. When moving into subalpine meadows, juniper forests, alpine meadows and meadows with Kobresia, as well 
as into the subnival zone of vegetation, the number of species of rust fungi decreases sharply.

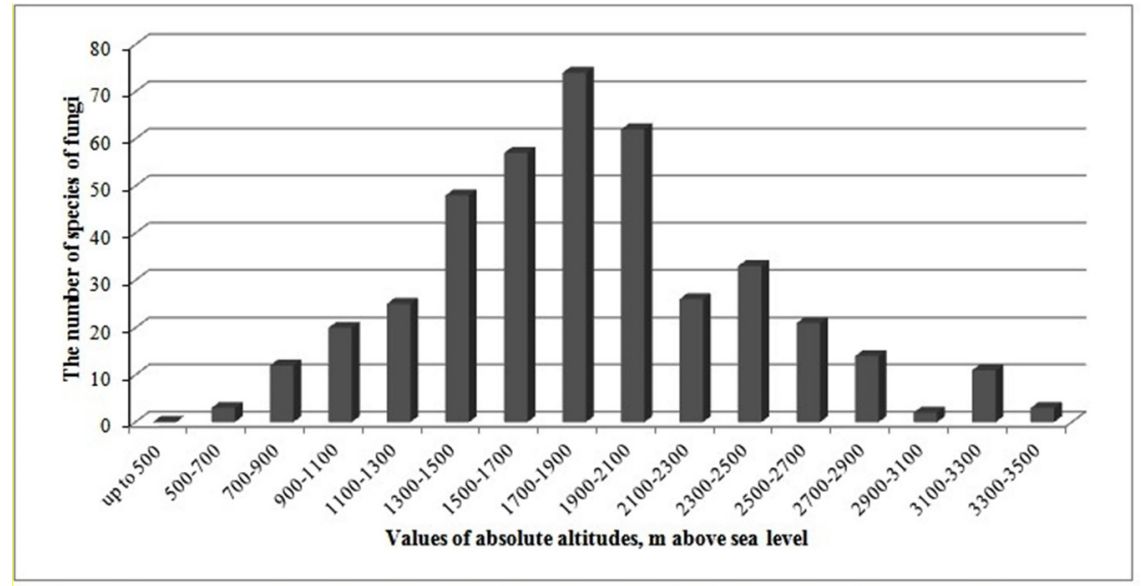

Figure 1. Distribution of rust fungi species according to vertical zoning

Since rust fungi are obligate parasites, their distribution is closely related to distribution of the host plant. 337 plant species from 165 genera are registered as host plants. In general, rust fungi are found in many locations of the Zailisky Alatau both on herbaceous plants, and on trees and shrubs (Figure 2).

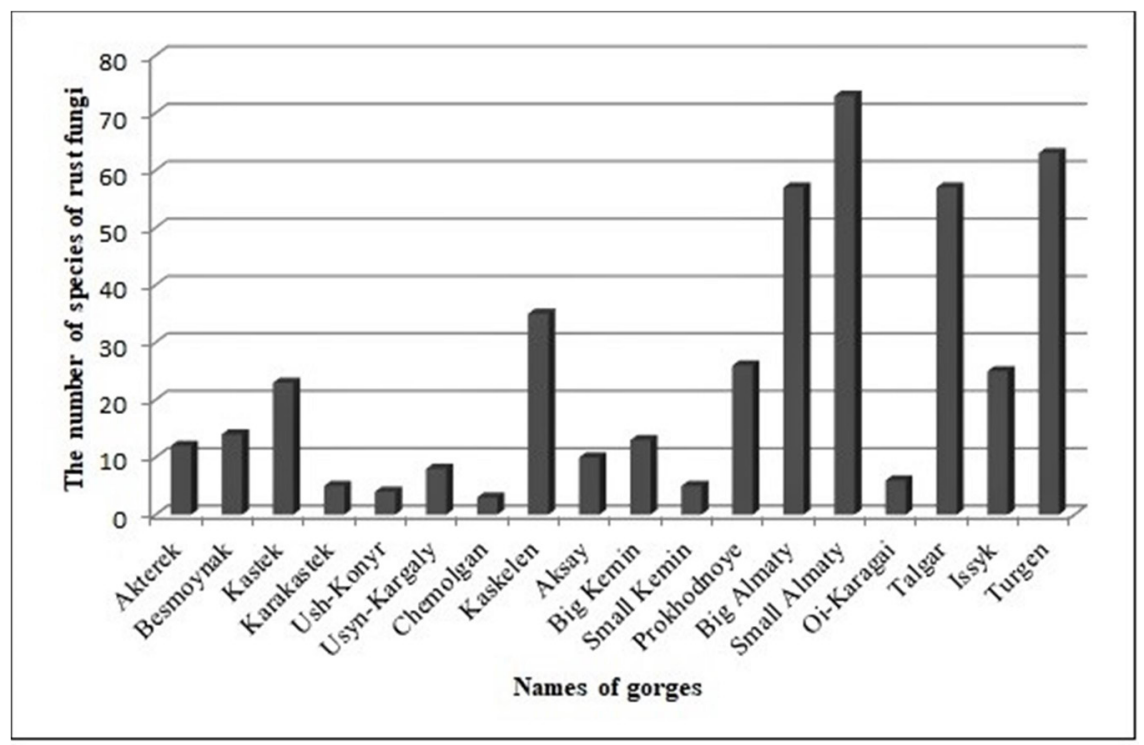

Figure 2. Distribution of rust fungi species in the gorges of Zailisky Alatau

The largest number of rust fungi species is noted in the Small and Big Almaty gorges (73 and 57 species, respectively), in the Talgar and Turgen gorges (57 and 63 species, respectively). The gorges of Karakastek, Ush-Konyr, Uzyn-Kargaly, Chemolgan, Small Kemin and Oi-Karagai are characterized by an insignificant diversity of rust fungi (from 3 to 8 species), which is associated with lower humidity of these gorges.

\section{Discussion}


Comparing our data with the literature $[9,10]$, it should be noted that the greatest similarity of the species composition of rust fungi is observed between Zailisky Alatau (176 species) and Terskei Alatau (107 species, taking into account modern taxonomic changes) (Table 2). The floristic similarity coefficient for these territories is $30 \%$ according to Jacquard $(\mathrm{Kj})$ and $49 \%$ according to Sørensen (Ks). 69 species of rust fungi are common for Zailiysky and Terskey Alatau. Representatives of the genera Microbotryum, Peristemma, and Hyalopsora are noted only in the Zailisky Alatau. A smaller number of species on the territory of the Ketmen ridge is due to its aridity, which is associated with its location in the desert zone, while rust fungi prefer moist habitats. In addition, the massif of the Dzhungar Alatau blocks the flow of moist air masses from the north to Ketmen.

Table 2. Diversity of rust fungi in Zailisky Alatau and neighboring territories

\begin{tabular}{|l|c|c|c|}
\hline \multirow{2}{*}{ Genus } & \multicolumn{3}{c|}{ The number of species of fungi in the territory } \\
\cline { 2 - 4 } & Zailisky Alatau & Terskei Alatau [9] & Ketmen [10] \\
\hline Microbotryum & 4 & - & - \\
\hline Sphacelotheca & 1 & 1 & - \\
\hline Aecidium & 10 & 8 & 1 \\
\hline Chrysomyxa & 2 & 3 & 1 \\
\hline Coleosporium & 1 & - & 1 \\
\hline Melampsora & 7 & 4 & 5 \\
\hline Phragmidium & 13 & 5 & 9 \\
\hline Trachyspora & 1 & 1 & 1 \\
\hline Gymnosporangium & 5 & 4 & 4 \\
\hline Peristemma & 1 & - & - \\
\hline Puccinia & 98 & 66 & 50 \\
\hline Uromyces & 24 & 14 & 12 \\
\hline Hyalopsora & 1 & - & - \\
\hline Melampsoridium & 1 & - & 1 \\
\hline Pucciniastrum & 4 & 1 & - \\
\hline Tranzschelia & 3 & - & $\mathbf{8 6}$ \\
\hline Total & $\mathbf{1 7 6}$ & $\mathbf{1 0 7}$ & \\
\hline
\end{tabular}

As for the distribution of rust fungi in the territory of Zailisky Alatau, the vegetation zones of dark coniferous and small-leaved forests and meadows are characterized with the maximum number of species. At the same time, great aridity does not allow fungi to develop intensively in the lower foothills and steppe zone, and low temperatures and intense solar insolation inhibit the development of rust fungi in the alpine and subalpine zones.

The wettest gorges in the Zailisky Alatau are gorges adjacent to the Talgar mountain junction, and the largest number of species of rust fungi is noted here, in the Small and Big Almaty gorges and in the Talgar gorge. In the direction east and west of the Talgar mountain junction, a significant decrease in humidity and, accordingly, a decrease in the diversity of rust fungi are observed.

The study was funded by the Ministry of Education and Science of the Republic of Kazakhstan under the program BR05236546 "Implementation by the State Botanical Gardens of the priority scientific and practical tasks of the Global Strategy for Plant Conservation as Sustainable Biodiversity Maintenance System” (Contract №340 from 03.04.2018).

\section{References}

1. G. S. Nevodovsky, Flora of spore plants of Kazakhstan. Rust fungi (Alma-Ata, 1956) 
2. B. K. Kalymbetov, Mycological flora of Zailisky Alatau (Northern Tien Shan) (AlmaAta, 1969)

3. S. A. Abiyev, Rust fungi of cereals of Kazakhstan. (Gylym, Almaty, 2002)

4. V. G. Transhel, Review of rust fungi of the USSR (Moscow-Leningrad, 1939)

5. Y. V. Rakhimova, G. A. Nam, B. D. Yermekova, S. A. Abiyev, U. K. Jetigenova, B. Zh. Yessengulova, Turczaninowia 18, 3 (2015)

6. R. G. Shivas, D. R. Beasley, A. R. McTaggart, IMA fungus, 5, 2 (2014)

7. P. F. Kirk, P. F. Cannon, J. C. David, J. A. Stalpers, Dictionary of the Fungi (10-th ed.). (CABI, Wallingford, 2008)

8. N. I. Akzhigitova, Z. V. Brekle, G. Winkler, E.A. Volkova et al., Botanical geography of Kazakhstan and Central Asia (within the desert region) (St. Petersburg, 2003)

9. A. A. Domashova, Mycoflora of the Terskey Alatoo ridge of the Kyrgyz SSR (Frunze, 1960)

10. Y.V. Rakhimova, G. A. Nam, B. D. Yermekova, U. K. Jetigenova, L. A. Kyzmetova, B. Zh. Yessengulova, Biodiversity of fungi of the desert lowlands in southeastern Kazakhstan and the Ketmen ridge (Luxe media publishing, Almaty, 2017) 